\title{
Cyrus Schayegh. Who Is Knowledgeable Is Strong. Science, Class, and the Formation of Modern Iranian Society, 1900-1950
}

\section{Bianca Devos}

\section{(2) OpenEdition \\ 1 Journals}

Electronic version

URL: http://journals.openedition.org/abstractairanica/40781

DOI: $10.4000 / a b s t r a c t a i r a n i c a .40781$

ISSN: 1961-960X

Publisher:

CNRS (UMR 7528 Mondes iraniens et indiens), Éditions de l'IFRI

\section{Printed version}

Date of publication: 1 December 2013

ISSN: 0240-8910

Electronic reference

Bianca Devos, « Cyrus Schayegh. Who Is Knowledgeable Is Strong. Science, Class, and the Formation of Modern Iranian Society, 1900-1950 », Abstracta Iranica [Online], Volume 32-33 | 2013, document 297 Online since 01 July 2016, connection on 26 September 2020. URL : http://journals.openedition.org/ abstractairanica/40781 ; DOI : https://doi.org/10.4000/abstractairanica.40781

This text was automatically generated on 26 September 2020.

Tous droits réservés 


\title{
Cyrus Schayegh. Who Is Knowledgeable Is Strong. Science, Class, and the Formation of Modern Iranian Society, 1900-1950
}

\author{
Bianca Devos
}

\section{REFERENCES}

Cyrus Schayegh. Who Is Knowledgeable Is Strong. Science, Class, and the Formation of Modern Iranian Society, 1900-1950. Berkeley, University of California Press, 2009, 340 p., appendix, bibliography, index.

1 As Ferdousi's line "Who is knowledgeable is strong" (tavānā bovad har ke dānā bovad) in the title suggests, this book mainly focuses on modern science, in particular its significance for the "modern Iranian middle class", which shaped modernist discourse during the first half of the 20th century. Schayegh's remarkable scholarly research combines different approaches to modern Iranian history by using the concept of class as an analytical base for his study and writing of the history of modern medicine and science in Iran in view of theoretical considerations about the history of colonial science. For the author, modern scientific knowledge is "a strategic tool in the formation of a modern Iranian society" (p. 2). He examines its role for the emerging middle class in six chapters, which are grouped into two large parts framed by an introduction and a short conclusion.

2 An introductory chapter provides a historical overview of the domestic and international reasons for the initially limited spread of modern Western science since the 19th century and for its growing importance, from 1910 onwards, in shaping the new middle class. Drawing on Pierre Bourdieu's concept of capital, the next two chapters describe how modern science, adopted by members of the middle class, 
formed their cultural capital, which served as the basis for their educational profile, a distinct identity and their cultural practices. Owing to the expansion of higher modern education and of new job markets for science-based knowledge, this cultural capital could be turned into economic capital. This was crucial to the strengthening of the nascent middle class's position in Iranian society. However modern, educated Iranian physicians had to compete with both traditional healers and Western physicians.

The book's second part also comprises three chapters but is twice as long as the first. Its description of a practical dimension of modern scientific knowledge focuses on biomedical fields such as neurology, psychiatry, hygiene, eugenics, genetics and psychology, and shows how the modern middle class used these sciences to solve problems. Thus, "medicine and biomedical sciences crystallized into a strategy of wider social purpose" (p.6). This process, which Schayegh calls "medicalizing modernity", gained ground during the 1920s when, under Reza Pahlavi's authoritarian rule, modernist activities were possible only in cooperation with the state.

4 Schayegh dwells on three main aspects of the modernist concern with the individual's and nation's physical, mental, and moral health. Chapter four describes the discourse that emerged about the potential damage wrought by modernity, as modernists advocated a scientific model of the interdependent health of body and mind. Another major concern with regard to the nation's health and strength was Iran's demographic stagnation, the subject of the fifth chapter. Referring to Michel Foucault's biopower, Schayegh analyzes the modernist strategy for tackling the demographic problem by applying positive eugenics, neo-Lamarckian genetics and French models of hygiene. He draws the conclusion that Western biomedical models were not simply adopted, but rather adapted to Iranian needs and interests. The last chapter focuses on the role of psychology and the creation of will power and a sense of personal responsibility so that Iranians protect themselves from the dangers that modernity bears for them and and the nation.

Worth mentioning is the appendix with its list of advertisements by physicians in the Tehran daily Etțelāa ât between 1927 and 1939. The date of first publication as well as the advertiser's name and speciality are cited. Extensive endnotes provide detailed background information and useful suggestions for further reading. The wide range of primary sources is impressive and includes a long list of periodicals, material mainly from European archives and several doctoral dissertations by Iranian students abroad or at the University of Tehran. An index makes this very valuable study easily accessible.

\section{AUTHORS}

\section{BIANCA DEVOS}

Philipps-Universität, Marburg 